\title{
ANALISA SIMULASI DISTRIBUSI TEMPERATUR DAN TEKANAN MENGGUNAKAN APLIKASI ANSYS 15.0 PADA RUANG BAKAR TURBIN GAS UNTUK MENGETAHUI TINGKAT KEADAAN
}

\author{
Jeffry $^{1 *}$, Ikhwansyah Isranuri ${ }^{2}$, M. Sabri ${ }^{3}$, Syahrul Abda ${ }^{4}$, Marragi $\mathbf{M}^{5}$ \\ 1,2,3,4,5 Departemen Teknik Mesin, Fakultas Teknik, Universitas Sumatera Utara \\ Email: 24jeffryx4@gmail.com
}

\begin{abstract}
This research was conducted to determine the conditions in the combustion chamber of a gas turbine type Silo Chamber and the distribution of temperature and pressure in it using ANSYS simulation. The data entered in the form of 8.5 bar compressed air and temperature of $722 \mathrm{~K}$, and fuel in the form of natural gas (CH4) with an inlet velocity of $20 \mathrm{~m} / \mathrm{s}$ and a temperature of $300 \mathrm{~K}$. The result is the highest temperature, pressure, and velocity of air flow in the middle of the combustion chamber where at an interval of $5<y<7 \mathrm{~m}$ from the main axis.
\end{abstract}

Keywords : Temperature and Pressure Distribution, Silo Combustion Chamber, ANSYS 15.0

\begin{abstract}
Abstrak
Penelitian ini dilakukan untuk mengetahui kondisi di dalam ruang bakar turbin gas jenis Silo Chamber dan pendistribusian temperatur dan tekanan di dalamnya dengan menggunakan simulasi ANSYS. Data yang dimasukkan berupa udara kompresi bertekanan 8.5 bar dan temperatur $722 \mathrm{~K}$, serta bahan bakar berupa gas alam $\left(\mathrm{CH}_{4}\right)$ dengan kecepatan masuk $20 \mathrm{~m} / \mathrm{s}$ dan temperatur $300 \mathrm{~K}$. Hasilnya adalah temperatur, tekanan, dan kecepatan aliran udara (velocity) tertinggi berada di tengah ruang bakar dimana pada posisi interval $5<\mathrm{y}<7 \mathrm{~m}$ dari sumbu utama.
\end{abstract}

Kata kunci : Distribusi temperatur dan tekanan, Silo Combustion Chamber, ANSYS 15.

\section{PENDAHULUAN}

Semakin bertambahnya jumlah penduduk berarti semakin bertambah pula kebutuhan akan energi listrik. Salah satu solusi untuk memecahkannya yaitu dengan membangun PLN (Perusahaan Listrik Negara) sebagai penyedia energi listrik. Namun, untuk dapat memenuhi kebutuhan listrik negara, PLN juga harus dengan cermat memantau kondisi dari alat pembangkit listrik yang dalam hal ini adalah turbin gas. Hal ini dapat dilakukan dengan cara analisa terhadap kondisi di dalam ruang bakar (combustion chamber) dari turbin gas. Dengan menggunakan software ANSYS, kondisi di dalam ruang bakar dapat disimulasikan dan dianalisa temperatur, tekanan, dan kecepatan aliran udara (velocity) dengan akurat.

\section{TEORI DASAR}




\subsection{Turbin Gas}

Turbin gas adalah suatu alat yang memanfaatkan gas sebagai fluida untuk memutar turbin dengan memanfaatkan kompresor dan mesin pembakaran internal. Di dalam turbin gas, energi kinetik dikonversikan menjadi energi mekanik melalui udara bertekanan yang memutar sudu turbin sehingga menghasilkan daya. Sistem turbin gas terdiri dari tiga komponen utama, yaitu kompresor, ruang bakar, dan turbin.

Secara umum proses yang terjadi pada suatu sistem turbin gas adalah sebagai berikut:

a. Pemampatan (compression) udara di hisap dan dimampatkan.

b. Pembakaran (combustion) bahan bakar dicampurkan ke dalam ruang bakar dengan udara kemudian di bakar.

c. Pemuaian (expansion) gas hasil pembakaran memuai dan mengalir ke luar melalui nozel (nozzle).

d. Pembuangan gas (exhaust) gas hasil pembakaran dikeluarkan lewat saluran pembuangan.
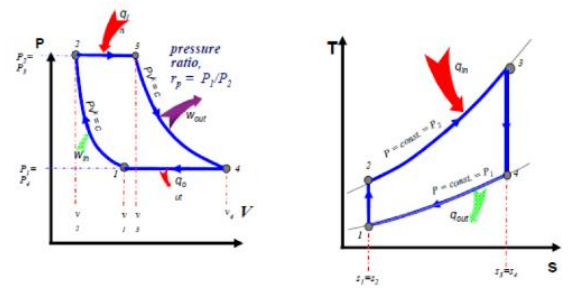

Gambar 2.1 Diagram P-V dan T-S Turbin Gas Ideal

\subsection{Combustion Chamber}

Combustion Chamber atau combustor juga dikenal sebagai burner, ruang pembakaran atau pemegang api. Dalam mesin turbin gas, ruang bakar (combustor atau combustion chamber) diumpankan oleh udara bertekanan tinggi dari sistem kompresi. Combustor kemudian memanaskan udara ini pada tekanan konstan. Setelah pemanasan, udara melewati dari ruang bakar melalui panduan baling-baling nozel untuk turbin. Fungsi ruang bakar adalah untuk mengubah energi tekanan menjadi energi panas melalui proses pembakaran.

\section{Silo Combustion Chamber}

Ruang pembakaran silo untuk turbin gas yang memiliki tabung api, dinding dalam, tabung api, dinding luar yang mengelilingi dinding bagian dalam, dan sejumlah rongga untuk jalur suplai fluida, sejumlah pembakar yang masing-masing terbuka ke ruang pembakaran melalui lubang tabung api. Silo combustion chamber digunakan pada skala industri besar. Biasanya terdiri dari 2 buah pada sebuah unit turbin gas. Pada silo combustion chamber biasanya terdapat 6 atau 8 pembakar di dalamnya. 


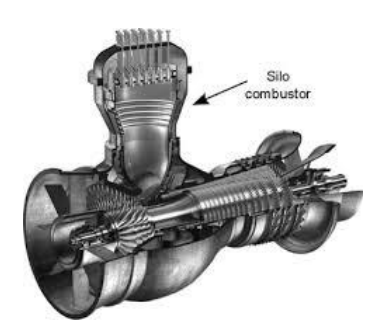

Gambar 2.2 Silo Combustor

Pasokan oksigen terhubung secara fluida ke ruang annular. Desain silo combustion chamber yang sederhana ini memudahkan untuk dilakukan perawatan (maintenance). Di dalam dinding ruang bakarnya dipasang keramik-keramik persegi panjang untuk memperlambat perpindahan panas ke luar chamber. Udara panas hasil pembakaran akan langsung menuju nosel turbin. Silo combustion chamber memiliki ukuran yang paling besar di antara semua jenis combustion chamber

\subsection{ANSYS Workbench}

ANSYS Workbench adalah salah satu perangkat lunak berbasiskan metode elemen hingga yang dipakai untuk menganalisa masalah-masalah rekayasa (engineering). ANSYS Workbench menyediakan fasilitas untuk berinteraksi antar solvers famili ANSYS. ANSYS Workbench juga dapat berintegrasi dengan perangkat lunak CAD sehingga memudahkan pengguna dalam membangun model geometri dengan berbagai perangkat lunak $\mathrm{CAD}$.

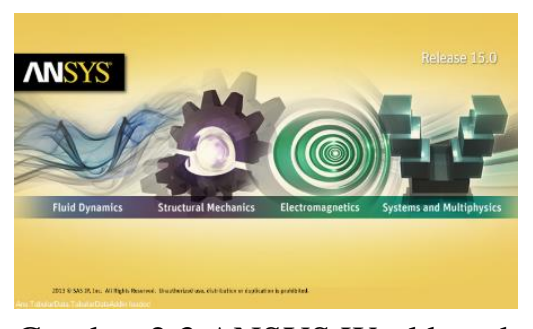

Gambar 2.3 ANSYS Workbench

ANSYS Workbench berisi beberapa fasilitas, di antaranya:

1. Mechanical, untuk analisa struktur (statik) dan thermal (perpindahan panas)

2. Fluid Flow, yang terdiri dari ANSYS CFX dan Fluent, untuk analisa CFD (computational fluid dynamics).

3. Engineering Data, sebagai database material lengkap dengan propertiesnya.

4. Design Modeler, digunakan untuk membangun geometri model yang akan dianalisa. Juga dapat digunakan untuk memodiifikasi hasil gambar dari perangkat lunak CAD.

5. Meshing Application, fasilitas untuk "meshing" baik pada CFD maupun Explicit Dynamics.

6. BladeGen, untuk membangun geometri blade, seperti fan, blower, sudu turbin dan lainlain.

Perhitungan yang mengkhususkan pada fluida, mulai dari aliran fluida, perpindahan panas, dan reaksi kimia yang terjadi pada fluida menggunakan CFD. Atas prinsip-prinsip 
dasar mekanika fluida, konservasi energi, momentum, massa, serta species, penghitungan dengan CFD dapat dilakukan. Secara sederhana proses penghitungan yang dilakukan oleh aplikasi CFD adalah dengan kontrol-kontrol penghitungan yang telah dilakukan maka kontrol penghitungan tersebut akan dilibatkan dengan memanfaatkan persamaanpersamaan yang terlibat. Persamaan-persamaan ini adalah persamaan yang dibangkitkan dengan memasukkan parameter apa saja yang terlibat dalam domain. Misalnya ketika suatu model yang akan dianalisa melibatkan temperatur berarti model tersebut melibatkan persamaan energi atau konservasi dari energi tersebut. Inisialisasi awal dari persamaan adalah boundary condition. Boundary condition adalah kondisi dimana kontrol-kontrol perhitungan didefinisikan sebagi definisi awal yang akan dilibatkan ke kontrol-kontrol penghitungan yang berdekatan dengannya melalui persamaan-persamaan yang terlibat.

\section{METODE PENELITIAN}

\subsection{Pre Processing}

a. Desain

Pendesainan combustion chamber menggunakan software Solidworks 2011. Kemudian model diexport ke software ANSYS Workbench 15.0.

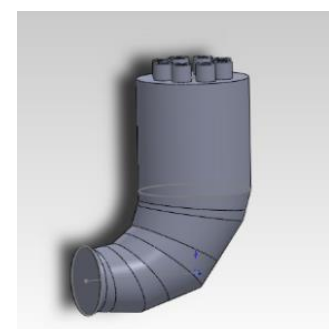

\section{Gambar 3.1 Model Silo Combustion Chamber}

\section{b. Input Data}

Masuknya udara hasil kompresi melalui 8 saluran udara di atas combustion chamber memiliki tekanan rata-rata 8.5 bar dan temperatur rata-rata $722 \mathrm{~K}$. Udara hasil kompresi ini memiliki komposisi yang terdiri dari $\mathrm{N}_{2} 76.7 \%$ dan $\mathrm{O}_{2} 23.3 \%$.

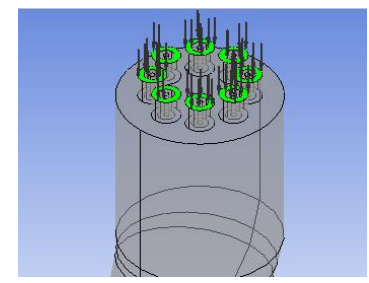

\section{Gambar 3.2 Saluran Masuk Udara Kompresi}

Bahan bakar dengan komposisi Natural Gas $\left(\mathrm{CH}_{4}\right)$ masuk melalui 8 saluran kecil dengan kecepatan masuk sebesar $20 \mathrm{~m} / \mathrm{s}$ dan temperatur bahan bakar $300 \mathrm{~K}$. 


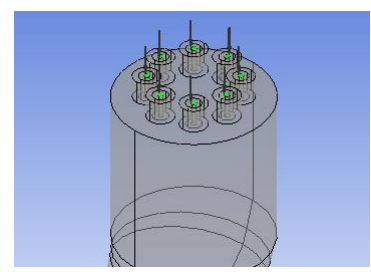

Gambar 3.3 Saluran Masuk Bahan Bakar

Hasil keluaran pembakaran di dalam combustion chamber digunakan tekanan keluar 8.5 bar. Hal ini sesuai dengan prinsip gas ideal, yaitu tekanan udara konstan selama proses di dalam ruang pembakaran.

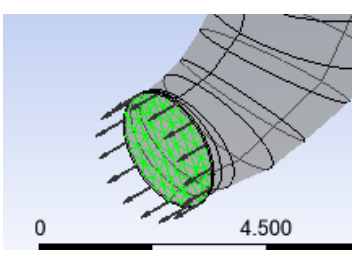

Gambar 3.4 Keluaran Hasil Pembakaran

\subsection{Post Processing}

Hasil dari simulasi menunjukkan kontur warna yang bervariasi pada distribusi temperatur, tekanan, dan velocity.

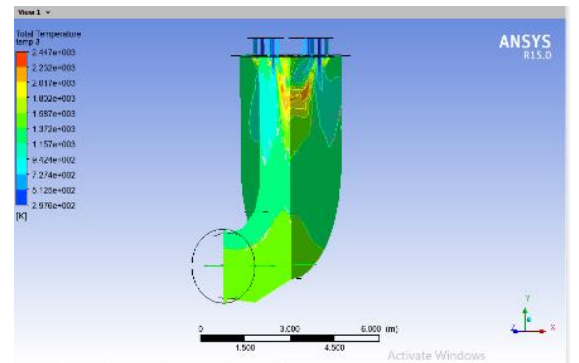

Gambar 3.5 Hasil Simulasi Temperatur

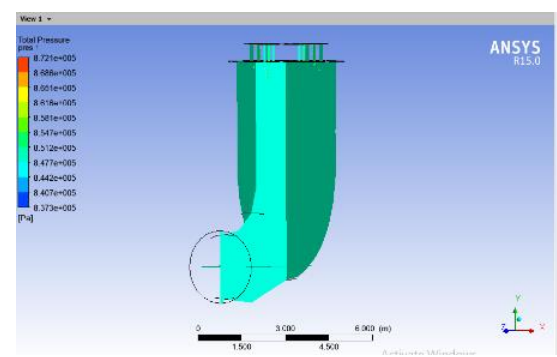

Gambar 3.6 Hasil Simulasi Tekanan 


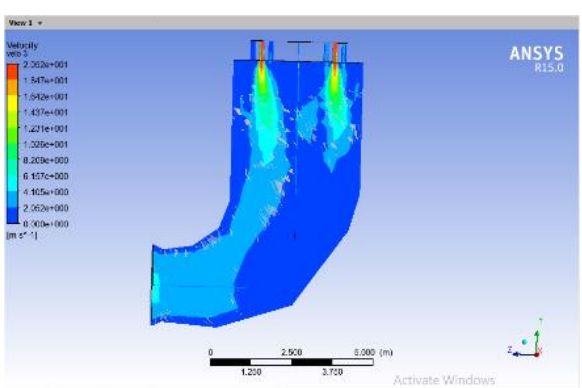

Gambar 3.7 Hasil Simulasi Velocity

\section{HASIL \& PEMBAHASAN}

\subsection{Analisa Distribusi Temperatur, Tekanan, dan Velocity}

\section{a. Bidang YZ}

Pada bidang YZ, dibuat lima garis vertikal untuk mendapatkan representasi dari distribusi temperatur, tekanan, dan velocity. Kemudian dibuatkan dalam bentuk grafik sumbu Y terhadap temperatur, sumbu Y terhadap tekanan, dan sumbu Y terhadap velocity. Temperatur-temperatur tertinggi berada pada interval $5<\mathrm{y}<7 \mathrm{~m}$. Tekanantekanan tertinggi berada pada interval $5<\mathrm{y}<7$. Velocity tertinggi berada pada interval 4 $<\mathrm{y}<6.5$.

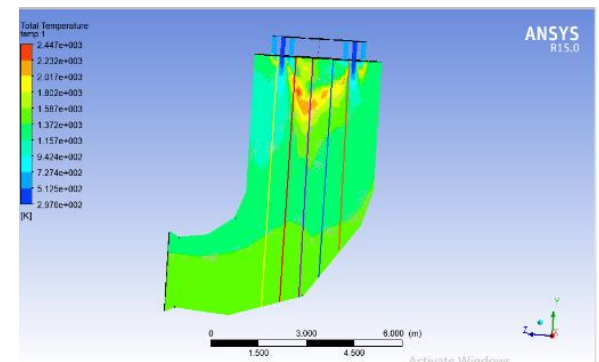

Gambar 4.1 Lima Garis Vertikal Bidang YZ

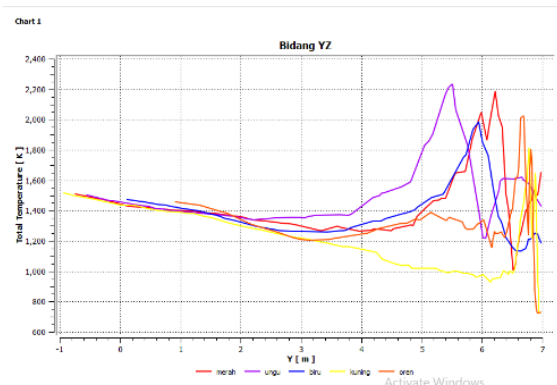

Gambar 4.2 Distribusi Temperatur Bidang YZ 


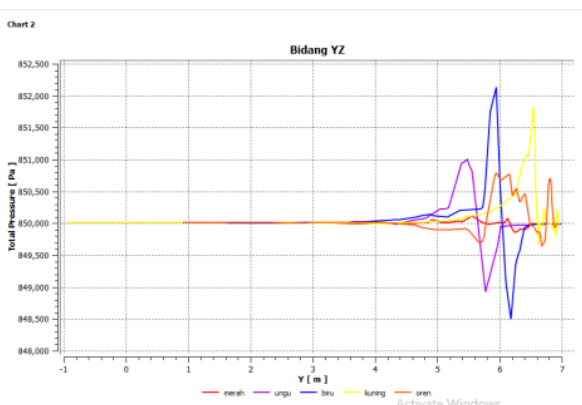

Gambar 4.3 Distribusi Tekanan Bidang YZ

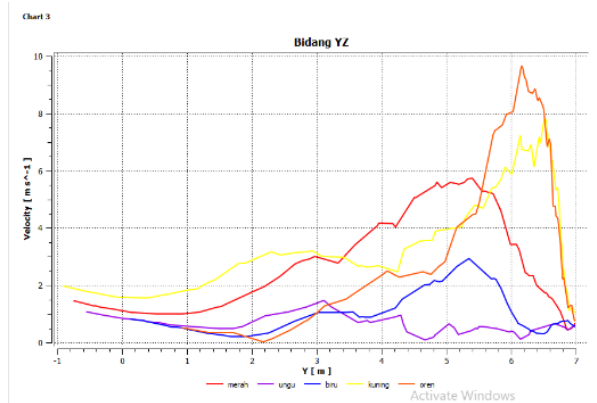

Gambar 4.4 Kontur dan Grafik Velocity Bidang YZ

Dari ketiga parameter, yaitu temperatur, tekanan, dan velocity dalam bidang YZ menunjukkan bahwa temperatur dan tekanan tertinggi berada pada interval $5<y<7 \mathrm{~m}$ dengan temperatur di antara $1800 \mathrm{~K}$ sampai $2200 \mathrm{~K}$ dan tekanan di antara $851000 \mathrm{~Pa}$ sampai $852000 \mathrm{~Pa}$. Sedangkan velocity tertinggi pada interval $6<\mathrm{y}<7 \mathrm{~m}$. Velocity yang tinggi tersebut terjadi bersamaan dengan naiknya temperatur dan tekanan.

\section{b. Bidang XY}

Pada bidang XY, dibuat lima garis vertikal untuk mendapatkan representasi dari distribusi temperatur. Kemudian dibuatkan dalam bentuk grafik sumbu $\mathrm{Y}$ terhadap temperatur, sumbu Y terhadap tekanan, dan sumbu Y terhadap velocity. Temperatur dan tekanan tertinggi berada pada interval $5<\mathrm{y}<7 \mathrm{~m}$. Velocity tertinggi berada pada interval $5<\mathrm{y}<6.5 \mathrm{~m}$.

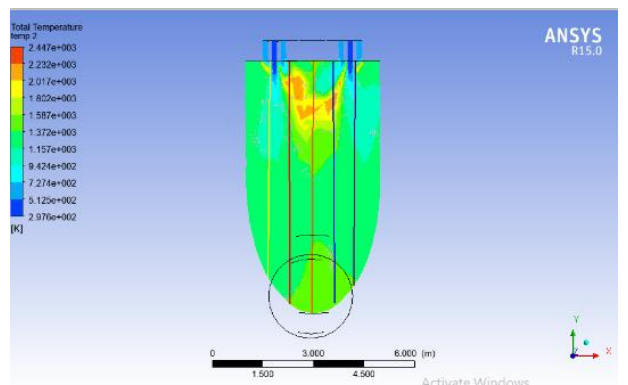

Gambar 4.5 Lima Garis Vertikal Bidang XY 


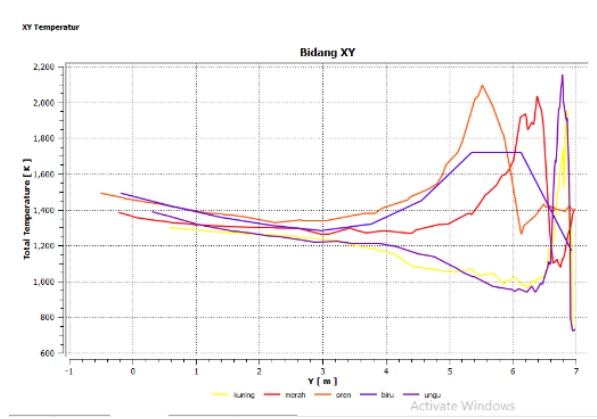

Gambar 4.6 Distribusi Temperatur Bidang XY

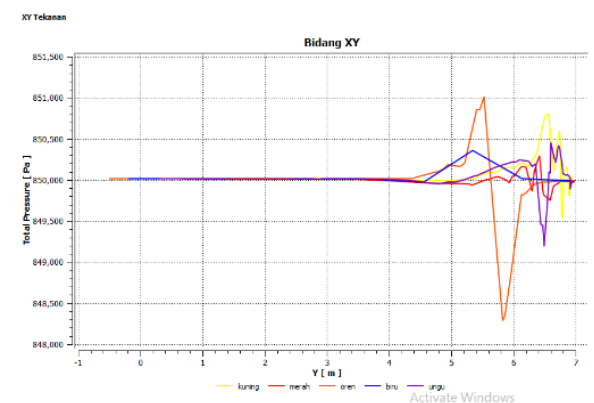

Gambar 4.7 Distribusi Tekanan Bidang XY

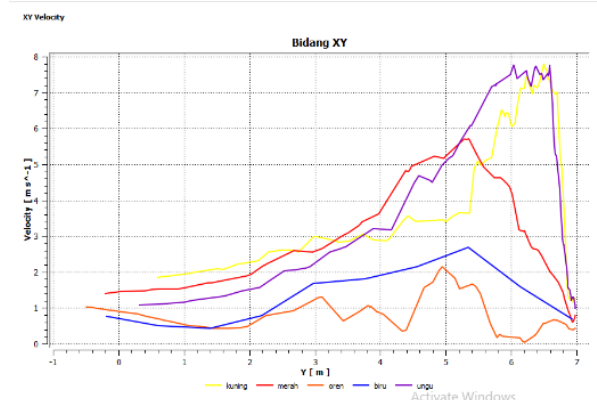

Gambar 4.8 Kontur dan Grafik Velocity Bidang XY

Bidang XY secara keseluruhan menunjukkan bahwa temperatur dan tekanan tertinggi berada pada interval $5<y<7 \mathrm{~m}$. Naik dan turunnya tekanan secara signifikan juga disertai dengan naik dan turunnya temperatur. Velocity tertinggi pada interval $5<y<6.5$ $\mathrm{m}$. Hal ini terjadi karena zona tersebut berdekatan dengan masuknya kompresi udara dan bahan bakar.

\section{c. Bidang XZ}

Pada bidang XZ, dibuat lima garis horizontal untuk mendapatkan representasi dari distribusi temperatur. Kemudian dibuatkan dalam bentuk grafik sumbu $Z$ terhadap temperatur, sumbu $\mathrm{Z}$ terhadap tekanan, dan sumbu $\mathrm{Z}$ terhadap velocity. Daerah temperatur tertinggi berada di zona garis biru dan oren. Tidak terjadi peningkatan atau penurunan tekanan yang signifikan. Jika dilihat melalui kontur warna, tekanan pada bidang XZ merata. Velocity di bidang XZ mengalami peningkatan $4-5 \mathrm{~m} / \mathrm{s}$ sebelum keluar dari outlet combustion chamber. 


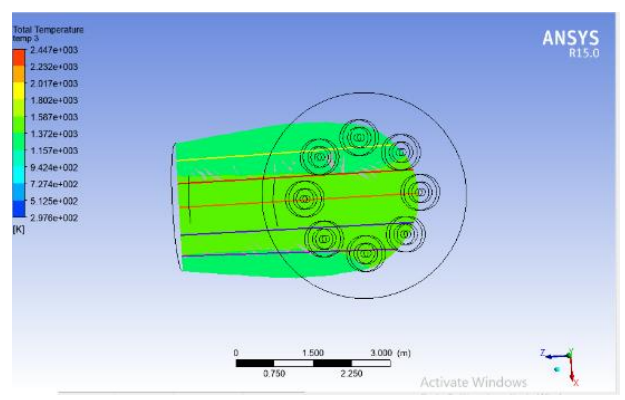

Gambar 4.9 Lima Garis Horizontal Bidang XZ

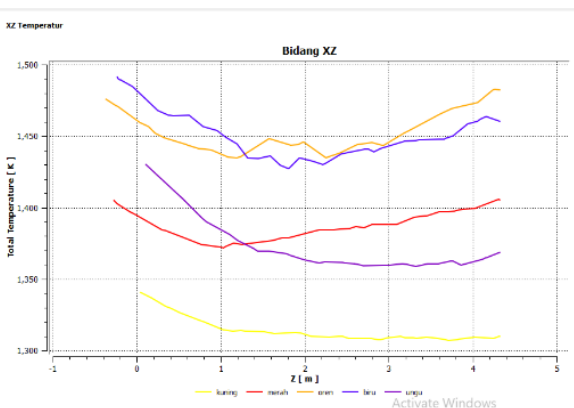

Gambar 4.10 Distribusi Temperatur Bidang XZ

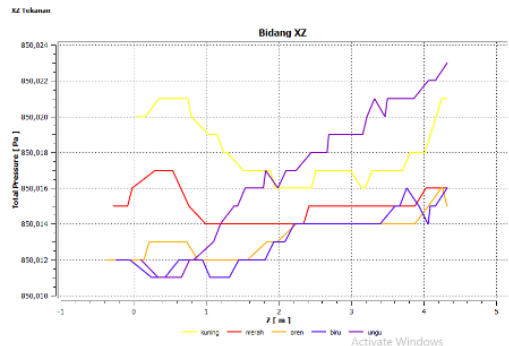

Gambar 4.11 Distribusi Tekanan Bidang XZ

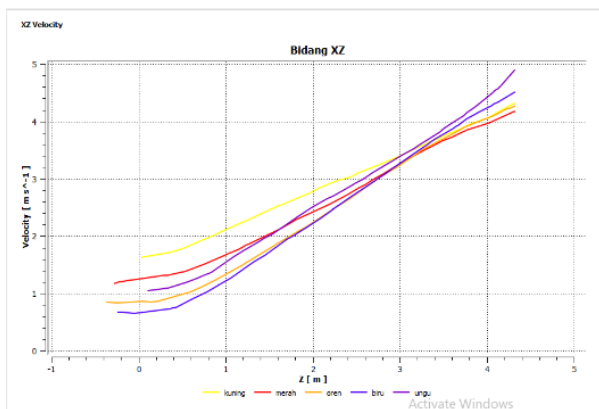

Gambar 4.12 Kontur dan Grafik Velocity Bidang XY

\subsection{Analisa 10 Titik}

Jika diambil beberapa titik pada bagian-bagian tertentu, dapat dilihat besar temperatur, tekanannya, dan velocity.

a. Bidang $X Y$ 


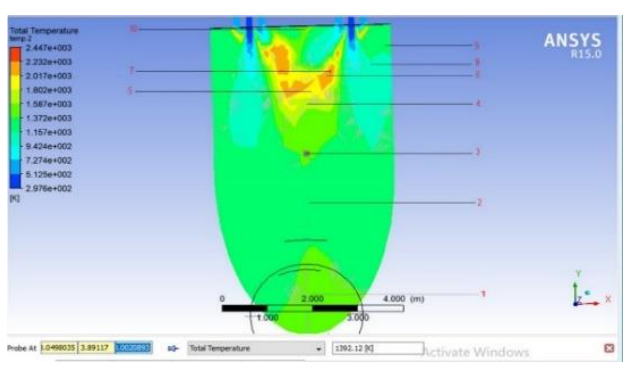

Gambar 4.13 Sepuluh Titik pada Bidang XY

Tabel 4.1 Data Temperatur, Tekanan, dan Velocity 10 Titik pada Bidang XY

\begin{tabular}{|c|c|c|c|c|c|c|}
\hline \multicolumn{7}{|c|}{ BIDANG XY } \\
\hline \multirow{2}{*}{} & \multicolumn{7}{|c|}{ Koordinat } & & Temperatur & Tekanan & Velocity \\
\cline { 2 - 7 } & $\mathrm{x}$ & $\mathrm{y}$ & $\mathrm{z}$ & $\mathrm{K}$ & $\mathrm{Pa}$ & $\mathrm{m} / \mathrm{s}$ \\
\hline 1 & 0.0772309 & 0.32547 & 0.003823 & 1450.49 & 850012 & 0.689455 \\
\hline 2 & 0.0326392 & 2.76692 & 0.005545 & 1337.52 & 850008 & 0.968034 \\
\hline 3 & 0.0498035 & 3.89117 & 0.002089 & 1392.12 & 850018 & 0.951398 \\
\hline 4 & 0.0639748 & 5.04631 & 0.002044 & 1645.69 & 850186 & 2.36384 \\
\hline 5 & 0.102866 & 5.3798 & 0.002204 & 1969.54 & 850745 & 1.67889 \\
\hline 6 & 0.531765 & 5.76917 & 0.00217 & 2127.12 & 849525 & 1.30421 \\
\hline 7 & 0.628299 & 5.86754 & 0.001008 & 2254.48 & 849841 & 1.87184 \\
\hline 8 & 1.52617 & 5.90622 & 0.00468 & 1136.62 & 850051 & 1.06962 \\
\hline 9 & 1.89974 & 6.52242 & 0.004035 & 1164.55 & 849996 & 1.98336 \\
\hline 10 & 0.131933 & 6.89535 & 0.001725 & 1404.44 & 849989 & 0.512692 \\
\hline
\end{tabular}

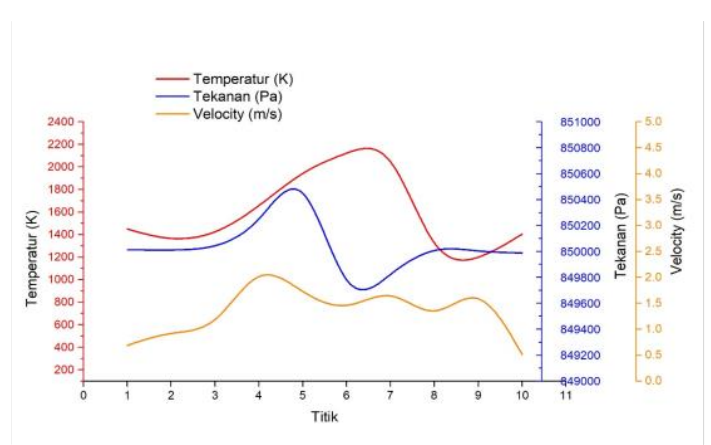

Gambar 4.14 Grafik Temperatur, Tekanan, dan Velocity 10 Titik pada Bidang XY

Pada titik 6, 7, dan 8 terjadi kenaikan dan penurunan temperatur dan tekanan yang tidak sebanding, dengan diikuti velocity yang fluktuatif. Hal ini menunjukkan pendistribusian tekanan yang tidak merata pada daerah tersebut.

b. Bidang YZ 


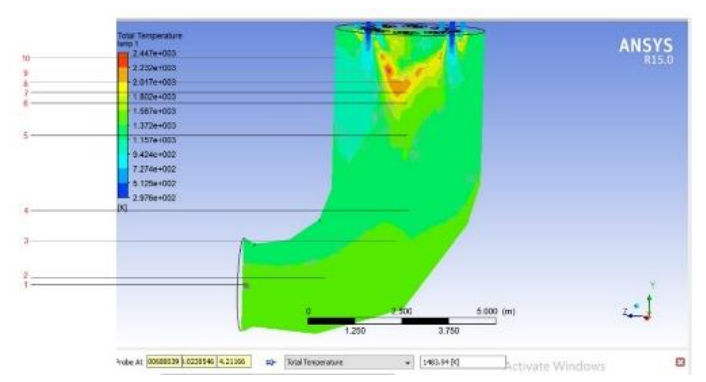

Gambar 4.15 Sepuluh Titik pada Bidang YZ

Tabel 4.2 Data Temperatur, Tekanan, dan Velocity 10 Titik pada Bidang YZ

\begin{tabular}{|c|c|c|c|c|c|c|}
\hline \multicolumn{7}{|c|}{ PLANE YZ } \\
\hline \multirow{2}{*}{} & \multicolumn{2}{|c|}{ Koordinat } & Temperatur & Tekanan & Velocity \\
\cline { 2 - 7 } & $\mathrm{x}$ & $\mathrm{y}$ & $\mathrm{z}$ & $\mathrm{K}$ & $\mathrm{Pa}$ & $\mathrm{m} / \mathrm{s}$ \\
\hline 1 & 0.00688 & -0.02385 & 4.21166 & 1483.94 & 850015 & 4.20156 \\
\hline 2 & 0.006646 & 0.209101 & 1.96279 & 1433.85 & 850013 & 2.23997 \\
\hline 3 & 0.006764 & 1.34142 & 0.222935 & 1386.2 & 850011 & 0.563913 \\
\hline 4 & 0.006683 & 2.14656 & -0.05101 & 1331.89 & 850009 & 0.55805 \\
\hline 5 & 0.006713 & 4.20326 & 0.002432 & 1435.28 & 850020 & 0.58217 \\
\hline 6 & 0.006581 & 5.05132 & -0.01021 & 1675.31 & 850165 & 2.0884 \\
\hline 7 & 0.006808 & 5.36363 & -0.03681 & 1921.71 & 850673 & 1.9401 \\
\hline 8 & 0.006571 & 5.50388 & 0.183685 & 2230.44 & 850837 & 0.35269 \\
\hline 9 & 0.002495 & 5.8848 & 0.560904 & 2394.65 & 849985 & 1.89357 \\
\hline 10 & 0.001695 & 6.11944 & 1.89218 & 1148.24 & 849994 & 2.02621 \\
\hline
\end{tabular}

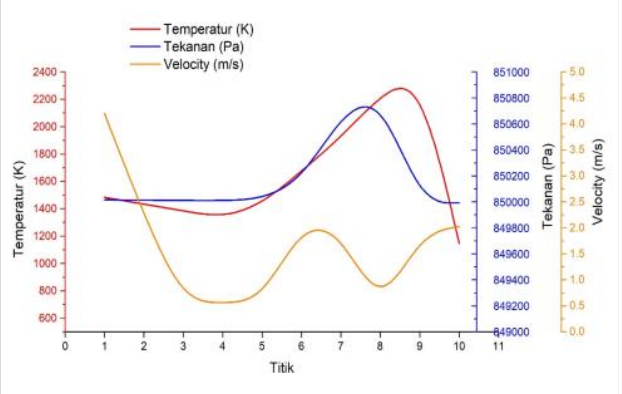

Gambar 4.16 Grafik Temperatur, Tekanan, dan Velocity 10 Titik pada Bidang YZ

Pada bidang YZ, terjadi kenaikan dan penurunan yang signifikan. Kenaikan temperatur juga diikuti oleh kenaikan tekanan. Velocity mengalami kenaikan dan penurunan yang fluktuatif.

c. Bidang XZ 


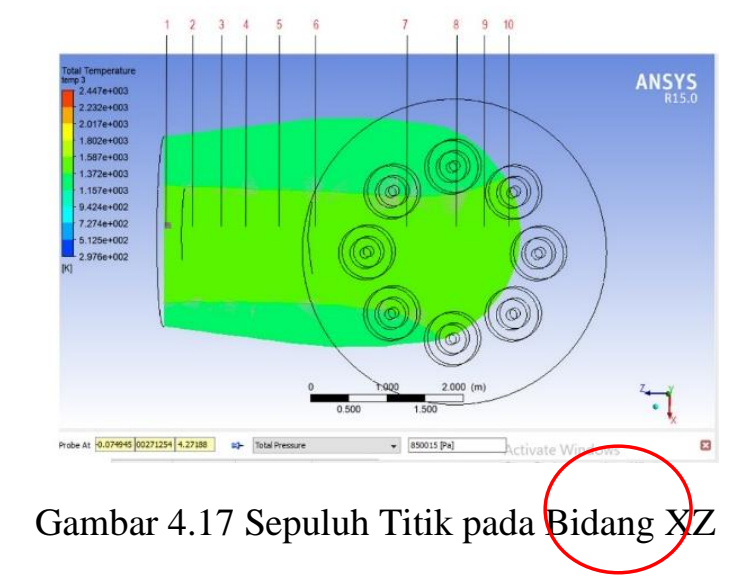

Tabel 4.3 Data Temperatur, Tekanan, dan Velocity 10 Titik pada Bidang XZ

\begin{tabular}{|c|c|c|c|c|c|c|}
\hline \multicolumn{7}{|c|}{ PLANE XZ } \\
\hline & \multicolumn{3}{|c|}{ Koordinat } & Temperatur & Tekanan & Velocity \\
\cline { 2 - 7 } & $\mathrm{x}$ & $\mathrm{y}$ & $\mathrm{z}$ & $\mathrm{K}$ & $\mathrm{Pa}$ & $\mathrm{m} / \mathrm{s}$ \\
\hline 1 & -0.07495 & 0.002713 & 4.27188 & 1472.46 & 850015 & 4.21491 \\
\hline 2 & -0.08647 & 0.002751 & 3.95184 & 1464.7 & 850015 & 3.99826 \\
\hline 3 & -0.08871 & 0.002802 & 3.56388 & 1455.56 & 850014 & 3.72826 \\
\hline 4 & -0.08077 & 0.002614 & 3.26319 & 1444.05 & 850014 & 3.49939 \\
\hline 5 & -0.07344 & 0.002745 & 2.85579 & 1436.97 & 850014 & 3.1033 \\
\hline 6 & -0.06701 & 0.002843 & 2.29321 & 1430.48 & 850014 & 2.53299 \\
\hline 7 & -0.04604 & 0.002456 & 1.17102 & 1429.44 & 850012 & 1.498 \\
\hline 8 & -0.0432 & 0.002341 & 0.835673 & 1436.2 & 850012 & 1.22291 \\
\hline 9 & -0.01796 & 0.002421 & 0.493503 & 1444.27 & 850013 & 0.991866 \\
\hline 10 & -0.19642 & 0.008366 & -0.10957 & 1439.09 & 850013 & 0.968173 \\
\hline
\end{tabular}

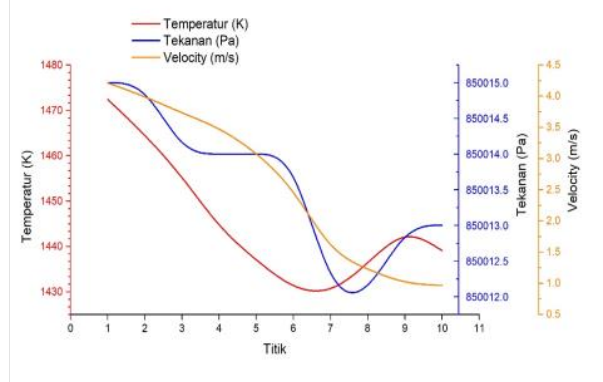

Gambar 4.18 Grafik Temperatur, Tekanan, dan Velocity 10 Titik pada Bidang XZ

Pada titik 4, 5, dan 6, penurunan tekanan tidak diikuti oleh penurunan temperatur. Hal ini menunjukkan pendistribusian tekanan yang tidak merata pada daerah tersebut. Secara keseluruhan, penurunan temperatur dan tekanan diikuti oleh penurunan velocity.

\subsection{Analisa Daerah Kritis}

Daerah kritis adalah daerah pada combustion chamber dimana terdapat temperatur yang tinggi (berwarna merah) yang dapat berpengaruh terhadap ketahanan material. Pada hasil simulasi, dapat dilihat bahwa daerah kritis terdapat di tengah ruang combustion chamber. Jika dianalisa menggunakan grafik-grafik di atas, maka daerah kritis tersebut berada pada posisi interval $5<\mathrm{y}<7 \mathrm{~m}$ dari sumbu utama. 


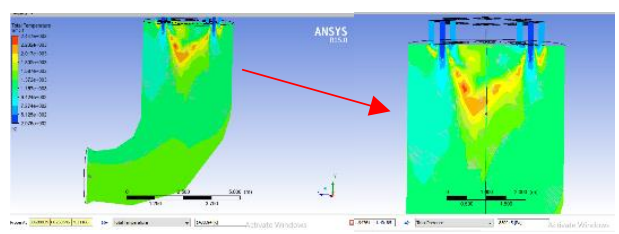

Gambar 4.19 Daerah Kritis

Pada daerah keluaran (outlet) combustion chamber, terlihat bahwa adanya kontur warna yang berbeda. Hal ini menunjukkan adanya temperatur yang tidak merata. Kondisi seperti ini dapat mempengaruhi putaran pada turbin.

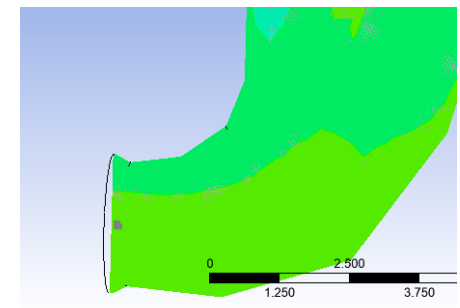

Gambar 4.20 Perbedaan Temperatur pada Outlet

Hasil simulasi ANSYS Workbench 15.0 menampilkan bahwa jangkauan temperatur tertinggi adalah $24474 \mathrm{~K}$, temperatur terendah adalah $297.567 \mathrm{~K}$, sedangkan jangkauan tekanan tertinggi adalah 872.075 Pa dan tekanan terendah adalah 837.254 Pa. Tetapi pada daerah luaran chamber, tidak terdapat kontur berwarna kritis. Temperatur luaran chamber berkisar dari $1100 \mathrm{~K}$ sampai $1430 \mathrm{~K}$. Combustion chamber menggunakan material seperti Nimonic 263, SS 309, Hastelloy X, atau Haynes 188. Dengan temperatur tersebut, maka combustion chamber tersebut masih aman untuk digunakan.

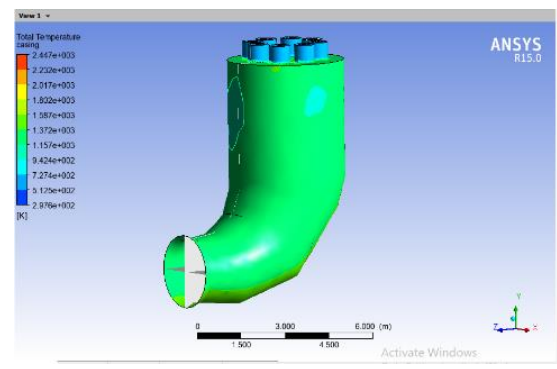

Gambar 4.21 Distribusi Temperatur pada Luaran Chamber

\section{KESIMPULAN DAN SARAN}

\subsection{Kesimpulan}

Adapun kesimpulan dari penelitian ini adalah sebagai berikut :

1. Daerah temperatur, tekanan, dan velocity tertinggi pada bidang $\mathrm{XY}, \mathrm{YZ}$ berada pada interval $5<\mathrm{y}<7 \mathrm{~m}$. Pada bidang $\mathrm{XZ}$, tidak terjadi peningkatan yang signifikan, tetapi velocity meningkat $4-5 \mathrm{~m} / \mathrm{s}$. 
2. Dalam pengambilan 10 titik pada bagian-bagian tertentu di ketiga bidang, secara keseluruhan naiknya temperatur diikuti dengan naiknya tekanan, dengan velocity yang fluktuatif.

3. Daerah kritis pada combustion chamber berada di tengah ruang chamber yang berjarak antara 5 sampai $7 \mathrm{~m}$ dari sumbu utama.

4. Material yang digunakan pada combustion chamber, yaitu Nimonic 263, SS 309, Hastelloy X, atau Haynes 188 masih aman untuk digunakan karena pendistribusian temperatur pada luaran chamber masih di bawah titik leleh material-material tersebut.

\subsection{Saran}

Adapun saran untuk penelitian yang lebih bagus ke depannya adalah sebagai berikut

1. Disarankan adanya penelitian lebih lanjut mengenai daerah temperatur dan tekanan yang fluktuatif pada bidang XY.

2. Disarankan adanya penelitian lebih lanjut mengenai konfigurasi burner terhadap pembakaran yang lebih homogen.

\section{REFERENSI}

Afrian, Rudy. 2010. Simulasi Aliran Udara 3D Pada Combustion Chamber Engine GE.J47-GE-17 Dengan Menggunakan Software Fluent. Sekolah Tinggi Teknologi Adisutjipto, Yogyakarta.
Arya.
Gas
Turbine
Maintenances
(Online)
https://arya1984.wordpress.com/2010/02/14/gas-turbine-maintenances/ (diakses 10 Juli 2019)

Cahyo, Nur. 2010. Simulasi Aliran Fluida Dalam Proses Pembakaran Natural Gas Pada Combustion Chamber. (Online) http://eprints.undip.ac.id/24522/1/L2E004424.pdf (diakses 12 Juli 2019)

James, Akash. Gas Turbine Combustion Chamber. (Online) https://www.rajagiritech.ac.in/Home/mech/Course_Content/Semester\%20IV/ME\% 20204\%20Thermal\%20Engineering/Module\%206.pdf (diakses 14 Juli 2019) 